\title{
Questes
}

vestes Revue pluridisciplinaire d'études médiévales

$10 \mid 2006$

Croire

\section{Croire : avant-propos}

Julien Abed

\section{(2) OpenEdition}

\section{Journals}

Édition électronique

URL : http://journals.openedition.org/questes/275

DOI : $10.4000 /$ questes. 275

ISSN : 2109-9472

\section{Éditeur}

Les Amis de Questes

\section{Édition imprimée}

Date de publication : 15 novembre 2006

Pagination : 1

ISSN : 2102-7188

\section{Référence électronique}

Julien Abed, «Croire : avant-propos », Questes [En ligne], 10 | 2006, mis en ligne le 01 janvier 2014, consulté le 25 septembre 2020. URL : http://journals.openedition.org/questes/275 ; DOI : https:// doi.org/10.4000/questes.275 


\section{Avant-propos}

Le groupe Questes présente avec ce dixième numéro du bulletin le résultat des interventions et discussions menées à la fin de l'année scolaire 20052006. Le sujet que nous avions choisi, «Croire», appelait tout un faisceau d'interrogations, tout un lot de concepts pour cerner le contenu de ce verbe si singulier lorsqu'on l'énonce seul, de façon intransitive. De la réflexion philosophique à l'évocation des enluminures, en passant par le champ littéraire, restant fidèles donc à la démarche pluridisciplinaire, nous avons tenté de découvrir ici les enjeux et les objectifs de l'acte de croire. Comme toujours, nous avons été conviés à déchiffrer les riches témoignages de l'activité intellectuelle médiévale, comme les résultats de recherches plus récentes - car la question, comme on dit, n'est pas neuve.

On retrouvera les différentes sections habituelles : courts articles, rédigés après les interventions orales, bibliographie, nécessairement succincte, comptes rendus des séances. Nous y avons ajouté un compte rendu, rédigé par Sophie Albert, du colloque de la Société de Langue et de Littérature Médiévales d'Oc et d'Oïl, qui s'est tenu à l'Université de Rennes II les 28 et 29 septembre 2006.

Bonne lecture. 